\title{
POŠTA
}

TELEKOMUNIKÁCIE A

ELEKTRONICKY OBCHOD

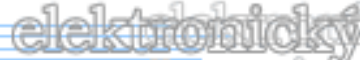

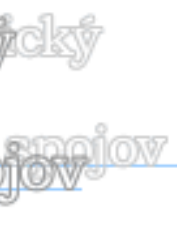

ANALÝZA REKLAMNÉHO ODVETVIA V SLOVENSKEJ REPUBLIKE

\section{Miriam Močková*}

\begin{abstract}
The advertising industry is a fast-growing industry and largely contributes to the gross domestic product in any country. Furthermore, the advertising industry operates as a link between producers, service providers and their customers, also plays an important role in the economy of the country.
\end{abstract}

Keywords: advertisment, advertising industry

Úvod

Pojem reklama sa odvodzuje z francúzštiny. Prvý raz sa toto slovo údajne objavilo v anglicko-francúzskom slovníku v roku 1611 ako pol’ovnícky termín. Kedysi reklama nebola potrebná, pretože na trhu bol zvyčajne iba jeden výrobca, respektíve výrobcovia nepôsobili globálne. Dopravné náklady boli vel'mi vysoké a umožňovali vznik lokálnych monopolov. Ale so začiatkom rozvoja ekonomiky a aj trhu sa začal konkurenčný boj medzi výrobcami. A práve týmto konkurenčným bojom nadobudla reklama na dôležitosti. Náhly príchod reklamy sa stretol s negatívnymi reakciami spotrebitel'ov. Jej prijímatelia sa tvárili, že ju k svojmu životu nepotrebujú, že ich otravuje a že sa ňou vôbec neriadia. Ale neskôr sa reklama stala neoddelitel'nou súčast'ou ich života. Reklama môže byt' vel'mi užitočným informačným zdrojom, ktorý orientuje zákazníka v ponuke, ale môže aj ovplyvňovat' a tým aj obmedzovat' spotrebitel'a. [1]

Reklama je hlavná súčast' komunikácie firiem s trhom, jedná sa o najznámejší a najrozšírenejší propagačný nástroj. Táto skutočnost' je daná širokou škálou a rozmanitost'ou foriem reklamy, možnost’ami ich kombinácie a uplatňovania neustále nových nápadov. Nie je jednoduché presne vyjadrit', ako by mala reklama vyzerat', aby zapôsobila na potenciálneho zákazníka a prinútila ho, aby si výrobok kúpil, alebo vyskúšal. Je umením dobre vytvorit', umiestnit' a načasovat' reklamu. V súčasnej dobe je reklama prítomná na každom kroku, agresívna a často krát vtieravá. To ako ju vnímame, ako na nás pôsobí, aký má pre nás význam a ako nás v konečnom dôsledku ovplyvní, záleží iba na nás. Podl'a J. Prachára reklama je platená forma neosobnej prezentácie a podpory myšlienok výrobkov alebo služieb, ktorú platí identifikovatel'ný sponzor. Týmto sponzorom môžu byt' jednotlivci, firmy alebo organizácie, ktorých snahou je prezentovat' svoje výrobky a služby na trhu. [2]

Prostredníctvom reklamy sa podniky snažia dostat' k zákazníkom informáciu, ktorá ich pozitívne ovplyvní, zanechá $\mathrm{v}$ nich odkaz a podnieti $\mathrm{k}$ uskutočneniu nákupu produktu alebo využit' služby. Za procesom jej tvorby sa skrýva mnoho faktorov spolupôsobiacich pri jej vzniku. Majú vplyv na jej konečnú formu a vzhl'ad. V konečnom dôsledku tu nejde len o podanie informácie o produkte resp. službe zo strany zadávatel’a reklamy, ale o upútanie

\footnotetext{
* Ing. Miriam Močková, PhD., Katedra spojov, FPEDAS, Žilinská univerzita v Žiline, Univerzitná 1, Žilina tel.: +421 415133 105, fax: +421 415655615

e-mail: Miriam.Mockova@fpedas.uniza.sk
} 
pozornosti zákazníka, čo tvorca resp. reklamná agentúra musí brat' do úvahy a zaoberat' sa týmto problémom. Je preto dôležité skíbit' tieto dve veci. Na jednej strane ide o informáciu, na strane druhej o upútanie pozornosti zákazníka. [3]

\section{Evolúcia reklamného odvetvia}

Začiatkom 19. storočia sa reklama začína oddel'ovat' od obchodu a možno pozorovat' jej relatívne samostatný vývoj. Vznikajú prvé reklamné agentúry (V. Británia 1800, USA 1840, ČSR 1927). Reklame sa začínajú venovat' špecialisti. Ukázalo sa výhodným zapojit' do nej celý rad technických vynálezov a objavov. Ťažisko sa zo zvukovej a vizuálnej reklamy v jej počiatočných formách presúva na vonkajšie reklamné prostriedky, ktoré nie sú bezprostredne viazané na miesto predaja, pretože tieto lepšie a rýchlejšie pomáhali splnit' reklamné ciele. Vznikajú moderné výkladné skrine, objav elektrickej energie, neónovej rúrky začína sa éra svetelnej reklamy, pre reklamu sa postupne využíva rozhlas, film, televízia, železničné a poštové zariadenie, poštové pečiatky, známky, pouličné lampy, brehy riek, lietadlá atd', skrátka všetko, čo okolie ponúkalo využit'. V 20. storočí sa reklama začleňuje do komplexu marketingových aktivít. Využíva všetky výdobytky vedecko-technického pokroku. Reklama dáva pracovné príležitosti miliónom špecialistov, prehlbuje špecializáciu práce, vynakladajú sa na ňu obrovské finančné čiastky.

Po technickej stránke až do roku 1926 bola v ČSR reklama na nízkej úrovni. Rok 1927 je medzníkom vo vývoji reklamy v ČSR, ked' bol založený Reklamný klub (Reklub) so sídlom v Prahe. Zaoberal sa aj vydávaním odbornej literatúry. V reklame sa začína prejavovat' vplyv americkej odbornej literatúry. Reklubu sa pripisuje aj zásluha na tom, že sa reklama stala učebným predmetom na niektorých školách.

Z výrazových prostriedkov reklamy sa používali najmä náborové listy, prospekty, katalógy, sezónne ponukové brožúry, inzeráty a pod., v kinoreklame sa využívali najmä diapozitívy, reklamné plagáty neboli tak časté a odlišovali sa od súčasných i grafickou úpravou. Zriedkavé boli aj reklamné filmy. Počas 2. svetovej vojny reklamné úsilie ochablo. Bezpečnostné a iné opatrenia vytláčali napr. svetelnú reklamu a obmedzili rozšírenie d’alších reklamných prostriedkov.

Vývoj reklamy a reklamnej činnosti po roku 1945 na Slovensku úzko súvisel s obnovou ekonomického a obchodného života krajiny. Povojnové ekonomicko-politické podmienky však rozvoju reklamy a reklamných prostriedkov nepriali. V znárodnenej časti hospodárstva a obchode zanikol zákon konkurencie, čím sa stratila aj potreba reklamy. Svoju úlohu však zohral aj všeobecný povojnový nedostatok tovaru. Trochu iná situácia bola v zatial' neznárodnenej časti hospodárstva, ktorú v rokoch tesne po vojne tvoril najmä vnútorný obchod. Súkromníci síce pocit’ovali potrebu reklamnej činnosti a poznali jej význam pre svoje obchodné aktivity, avšak pod vplyvom nedostatku tovaru, papiera i rôznych obmedzení nemohli reklamu obnovit' vo väčšom rozsahu a ani prispiet' $\mathrm{k}$ jej výraznejšiemu vývoju.

Udalosti vo februári 1948 nielenže spôsobili celkovú likvidáciu súkromného sektora a tým aj konkurencie, ale znamenali vlastne aj zánik komerčnej reklamy a reklamných aktivít. Reklama a reklamná činnost' vôbec začala byt' označovaná za akýsi charakteristický znak buržoáznej spoločnosti. Postupne však nastal určitý posun v chápaní formy a obsahu reklamy, ktorú nahradila propagácia nového typu $\mathrm{s}$ iným poslaním. Hlavnou úlohou propagácie $\mathrm{v}$ znárodnenom obchode sa stalo neustále informovanie obyvatel'stva o predávanom sortimente tovaru a o poskytovaných službách. Mnohé z propagačných prostriedkov však mali len nástennú formu a výkladová tvorba sa venovala najmä politickým dekoráciám.

Určitý kvalitatívny prelom nastal v roku 1957, ked' sa začala vysielat' televízna reklama. O rok neskôr pribudli aj pravidelné rozhlasové reklamné relácie. V rámci Československého štátneho filmu vzniklo aj prvé špeciálne štúdio na výrobu reklamných filmov, 
tzv. propagfilm. Vzhl'adom na absenciu trhového prostredia i na nedostatok konkurencie vo vlastných radoch strácala akákol'vek reklamná výpoved' svoje prvotné poslanie. Aj strata kontaktu s ostatným dynamicky sa rozvíjajúcim svetom a jednostranná orientácia mali za následok postupný úpadok tvorivej činnosti v oblasti vývoja reklamných prostriedkov.

Po roku 1989 sa aj u nás v plnom prúde začala rozvíjat' reklama. Vznikli stovky reklamných agentúr, vyšli mnohé publikácie z oblasti reklamy, uskutočnilo sa mnoho vzdelávacích aktivít, reklama na Slovensku si našla svoje miesto v trhovej ekonomike. [4]

\section{Trhový potenciál odvetvia}

V roku 2011 vzrástli výdavky zadávatel'ov do reklamy celkovo o 7\%, čím dosiahli úroveň takmer 880 miliónov eur. Vyplýva to z monitoringu reklamných výdavkov spoločnosti TNS Slovakia, ktorý vychádza z oficiálnych cenníkových cien a nezohl'adňuje zl'avy, bonusy a bartre. Nárast výdavkov do reklamy t’ahali predovšetkým televízie, ktoré zaznamenali medziročný nárast 18,2 \%. Pozitívny vývoj zaznamenáva posledné štyri roky aj kinoreklama, kde objem preinvestovaných reklamných výdavkov medziročne rastie. Najvýraznejší prepad zaznamenali noviny a rozhlas. Pokles zaznamenali aj časopisy a outdoorová reklama. (Tabul'ka 1)

Tabul'ka 1 Výdavky na reklamu za roky 2010 a 2011

\begin{tabular}{|l|r|r|c|}
\hline \multicolumn{1}{|c|}{ Media } & $\mathbf{2 0 1 0}$ & $\mathbf{2 0 1 1}$ & \% zmena \\
\hline Tv & 464489898 & 549121002 & $18,2 \%$ \\
\hline časopisy & 101388311 & 96115495 & $-5,2 \%$ \\
\hline noviny & 87585583 & 77402358 & $-11,6 \%$ \\
\hline outdoor & 80745173 & 76907603 & $-4,8 \%$ \\
\hline rádiá & 85049843 & 76837913 & $-9,7 \%$ \\
\hline kiná & 3083535 & 3179545 & $3,1 \%$ \\
\hline spolu & 822342343 & 879563916 & $7,0 \%$ \\
\hline
\end{tabular}

Zdroj: www.tns-global.sk

Výrazný pokles príjmov $\mathrm{z}$ reklamy $\mathrm{v}$ rádiách však nekorešpondoval s vývojom predaného reklamného priestoru, ten $\mathrm{v}$ rádiách vzrástol o takmer $2 \%$. V televízii bol nárast predaného reklamného priestoru iba vel'mi mierny $(0,2 \%)$. Pokles reklamných výdavkov v printoch kopíroval aj pokles počtu predaných inzertných strán. (Tabul'ka 2)

Tabul'ka 2 Celková dížka odvysielaných spotov v hodinách, resp. počet inzertných strán za r. 2010 a 2011

\begin{tabular}{|l|c|c|c|}
\hline \multicolumn{1}{|c|}{ Mediatyp } & $\mathbf{2 0 1 0}$ & $\mathbf{2 0 1 1}$ & \% zmena \\
\hline časopisy & 30305 inz. strán & 29183 inz. strán & $-7,0 \%$ \\
\hline noviny & 25779 inz. strán & 22601 inz. strán & $-12,3 \%$ \\
\hline rádia & 1918 hodín & 1954 hodín & $1,9 \%$ \\
\hline Tv & 4029 hodín & 4038 hodín & $0,2 \%$ \\
\hline
\end{tabular}

Zdroj: www.tns-global.sk

Aj ked' celková dížka reklamných spotov v televíziách zostala na takmer rovnakej úrovni ako v roku 2010, vzrástol počet odvysielaných spotov o $2 \%$. Z toho vyplýva, že zadávatelia vo väčšej miere v roku 2011 využívali kratšie trvanie spotov. Opačná situácia bola $\mathrm{v}$ rádiách, kde medziročne poklesol počet odvysielaných reklám o $4 \%$, ale objem predaného reklamného času vzrástol o $2 \%$. (Tabul'ka 3)

Tabul'ka 3 Množstvo odvysielaných spotov, resp. zverejnených vizuálov za roky 2010 a 2011 (v počte ks)

\begin{tabular}{|l|r|r|c|}
\hline \multicolumn{1}{|c|}{ Mediatyp } & $\mathbf{2 0 1 0}$ & $\mathbf{2 0 1 1}$ & \% zmena \\
\hline časopisy & 40889 & 39638 & $-3,0 \%$ \\
\hline noviny & 64519 & 56498 & $-12,0 \%$ \\
\hline rádia & 282456 & 272290 & $-4,0 \%$ \\
\hline Tv & 638428 & 652005 & $2,0 \%$ \\
\hline
\end{tabular}

Zdroj: www.tns-global.sk 
Najväčším zadávatel’om reklamy bol rovnako ako v roku 2010 aj v roku 2011 Slovak Telekom. Poradie 5 najväčších zadávatel'ov sa oproti roku 2010 vôbec nezmenilo.

Do TOP 10 zadávatel'ov sa dostali všetci traja mobilní operátori, Lidl ako jediný obchodný ret’azec, Slovenská sporitel'ňa ako jediná banka a Škoda Auto Slovensko ako jediný zástupca automotive segmentu. S výnimkou spoločnosti Procter\&Gamble boli všetci ostatní zadávatelia v TOP 10-ke aj v roku 2010. Procter\&Gamble vypadol z TOP 10 zadávatel'ov - zo 6.miesta v roku 2010 sa v roku 2011 dostal na 11.miesto. V rebríčku najvýznamnejších zadávatel'ov ho nahradila Škoda Auto Slovensko, L'Oreal a Telefónica. (Tabul'ka 4)

Tabul'ka 4 Poradie najväčších zadávatel'ov reklamy v SR za roky 2011

\begin{tabular}{|l|l|c|c|}
\hline \multicolumn{1}{|c|}{ Zadávatel' } & výdavky 2011 & \% zmena oproti 2010 \\
\hline 1 & Slovak Telekom & 40558952 & $-11 \%$ \\
\hline 2 & Orange & 37914127 & $5 \%$ \\
\hline 3 & Henkel & 21288065 & $3 \%$ \\
\hline 4 & Unilever & 17660755 & $-6 \%$ \\
\hline 5 & Lidl & 14602944 & $-5 \%$ \\
\hline 6 & Telefónica O2 & 14248597 & $16 \%$ \\
\hline 7 & L'Oreal & 13623700 & $40 \%$ \\
\hline 8 & Slovenská sporitel'ňa & 13241637 & $9 \%$ \\
\hline 9 & Nestlé & 12389223 & $5 \%$ \\
\hline 10 & Śkoda Auto Slovensko & 12337370 & $53 \%$ \\
\hline
\end{tabular}

Zdroj: www.tns-global.sk

Na desiatku najväčších zadávatel'ov pripadlo $22 \%$ celkových reklamných výdavkov v roku 2011. $81 \%$ z rozpočtu najväčších zadávatel'ov smerovalo do reklamy v televízii.

\section{Reklama v tlači}

V roku 2012 poklesol objem inzertných výdavkov v slovenských printových médiách. Vyplýva to z monitoringu reklamných výdavkov spoločnosti TNS Slovakia, ktorý vychádza z oficiálnych cenníkov a nezohl'adňuje žiadne zl'avy, bartre a bonusy. (Tabul'ka 5)

Tabul'ka 5 Vývoj výdavkov do reklamy v printových médiách (v mil. €) za roky 2011 a 2012

\begin{tabular}{|l|c|c|c|}
\hline & $\mathbf{2 0 1 1}$ & $\mathbf{2 0 1 2}$ & \% zmena \\
\hline PRINTY SPOLU & 173,38 & 168,67 & $-2,70 \%$ \\
\hline z toho Časopisy & 96,52 & 92,49 & $-4,20 \%$ \\
\hline z toho Noviny & 76,85 & 76,18 & $-0,90 \%$ \\
\hline
\end{tabular}

Zdroj: www.tns-global.sk

Zadávatelia investovali v roku 2012 do printovej reklamy viac ako 168 mil. eur a printový trh tak zaznamenal medziročne pokles príjmov z reklamy o $2,7 \%$. Výdavky na reklamu v novinách poklesli o necelé percento, pričom výdavky do časopisov poklesli výraznejšie, a to o $4 \%$.

V roku 2012 sa predalo 49318 inzertných strán, čo znamená takmer $5 \%$ pokles oproti roku 2011, pričom vo väčšej miere sa predali inzertné strany v časopisoch. (Tabul'ka 6)

Tabul'ka 6 Vývoj počtu predaných inzertných strán v roku 2012 vs. 2011

\begin{tabular}{|l|c|c|c|}
\hline & $\mathbf{2 0 1 1}$ & $\mathbf{2 0 1 2}$ & \% zmena \\
\hline PRINTY SPOLU & 51851 & 49318 & $-4,90 \%$ \\
\hline z toho Časopisy & 29249 & 27113 & $-7,30 \%$ \\
\hline z toho Noviny & 22601 & 22204 & $-1,80 \%$ \\
\hline
\end{tabular}

Zdroj: www.tns-global.sk

$\mathrm{Na} 5$ najväčších vydavatel'stiev na Slovensku pripadlo takmer $73 \%$ celkových reklamných výdavkov. (Tabul'ka 7) 
Tabul'ka 7 Reklamné výdavky v printe za rok 2012

\begin{tabular}{|l|c|c|c|}
\hline \multicolumn{1}{|c|}{ Vydavatel'stvo } & $\mathbf{2 0 1 2}$ & zmena oproti 2011 & $\begin{array}{c}\text { podiel na printovom } \\
\text { trhu }\end{array}$ \\
\hline RINGIER AXEL SPRINGER & $44056656 €$ & $4 \%$ & $26 \%$ \\
\hline SPOLOČNOSŤ 7 PLUS & $33060295 €$ & $-3 \%$ & $20 \%$ \\
\hline PETIT PRESS & $25624722 €$ & $-8 \%$ & $15 \%$ \\
\hline PEREX & $12671462 €$ & $-10 \%$ & $8 \%$ \\
\hline ECOPRESS & $6946283 €$ & $4 \%$ & $4 \%$ \\
\hline
\end{tabular}

Zdroj: www.tns-global.sk

Medzi mesačníkmi investovali zadávatelia už tradične najviac prostriedkov do reklamy v časopise Eva. Eva drží prvenstvo medzi mesačníkmi už niekol'ko rokov. Medzi týždenníkmi sa najviac inzerovalo v Plus 7 dní a čo sa týka denníkov, prvenstvo si drží Nový čas.

Medziročne stúpol záujem o merchandising, t.j. vkladanie vzoriek produktov k printom, o $34 \%$. Záujem o vkladanú inzerciu v novinách a časopisoch sa udržal na rovnakej úrovni ako v roku 2011.

Najväčším zadávatel'om reklamy v tlači bol tak ako aj v roku 2012 Orange, nasledovaný predajcom záhradnej a bazénovej techniky (Mountfield) a d'alším mobilným operátorom (Slovak Telekom). (Tabul'ka 8)

Tabul'ka 8 Top 10 zadávatel'ov v tlači v roku 2012

\begin{tabular}{|l|l|c|}
\hline & Zadávatel' & Suma v $€$ \\
\hline 1 & Orange Slovensko & $5206016 €$ \\
\hline 2 & Mountfield & $3759904 €$ \\
\hline 3 & Slovak Telecom & $3542523 €$ \\
\hline 4 & Rozhlas a televízia Slovenska & $3054026 €$ \\
\hline 5 & Škoda Auto Slovensko & $2967921 €$ \\
\hline 6 & Agentúra Megavox & $2528373 €$ \\
\hline 7 & Porsche Slovakia & $2175059 €$ \\
\hline 8 & Billa & $1929275 €$ \\
\hline 9 & Rádio Express & $1910727 €$ \\
\hline 10 & Lidl & $1888542 €$ \\
\hline
\end{tabular}

Zdroj: www.tns-global.sk

Monitoring reklamných výdavkov vychádza z oficiálnych cenníkových cien a nezohl'adňuje bartre, bonusy a agentúrne provízie. TNS Slovakia monitoruje 8 celoštátnych televíznych a 6 celoštátnych rozhlasových staníc, viac ako 100 printových titulov $\mathrm{s}$ celoslovenským aj regionálnym zameraním, 240 webových stránok a preberá údaje o reklame od 9 out-of-home agentúr, 2 kino spoločností a 1 mediálneho zastupitel'stva (zastrešuje 27 tematických TV staníc).

\section{Televízny reklamný priemysel}

Celoštátne slovenské televízne stanice odvysielali v roku 2012 takmer 769000 reklamných spotov v celkovej dížke 4770 hodín, čo je takmer 199 dní. Zadávatelia tak investovali do televízií za 12 mesiacov viac ako 632 miliónov eur. Vyplýva to z údajov spoločnosti TNS Slovakia.

Medziročne rástlo množstvo reklamy aj výdavky na ňu. V roku 2011 sa investovalo zhruba 550 miliónov eur za súhrnných 4038 hodín reklamných spotov. Ich priemerná dížka bola v roku 2012 rovnaká ako v roku 2011, teda 22 sekúnd. Medziročne sa však zvýšil počet tradičných 30-sekundových spotov, a to zhruba o pätinu. Najväčší podiel na odvysielanej reklame mali súkromné televízne stanice TV JOJ a TV Markíza. Obe televízie spoločne z časového hl'adiska odvysielali polovicu reklamy roku 2012. Ďalších $23 \%$ všetkej reklamy mohli diváci sledovat' na stanici Plus. Najväčším zadávatel’om televíznej reklamy bol rovnako ako v predošlých rokoch Slovak Telekom, ktorého výdavky sa odhadujú na takmer 35 
miliónov eur. Z rebríčka prvých desiatich zadávatel'ov vlani vypadol Procter\&Gamble. Nahradila ho Poštová banka, ktorej minuloročné výdavky na televízny marketing sa odhadujú na vyše 12 miliónov eur.

Podl'a dížky odvysielaných reklám bolo najviac TV spotov na TV Joj ( $28 \%$ z celkovej stopáže všetkých reklám), až potom na Markíze (26\%). Hoci trhový podiel Doma bol niekol'konásobne nižší ako share materskej televízie Markíza, na Dome bolo odvysielaných až $21 \%$ z celkovej stopáže reklám. Pri JOJ Plus bol podiel $16 \%$. Nasledovala Ta3 (6 \%), Jednotka a Dvojka STV boli na chvoste (2\%, resp. $1 \%)$. [5]

\section{Reklamný priemysel v rádiách}

Najväčším zadávatel’om reklamy v rádiách bola spoločnost' Škoda Auto Slovensko. Ako vyplýva z monitoringu reklamných výdavkov spoločnosti TNS Slovakia, objem investícií do reklamy v 6 celoštátnych slovenských rádiách stúpol v roku 2012 o necelých 6 $\%$. Najviac reklamy predalo rádio Expres, Fun rádio a rádio Viva. Poradie dopíňajú Jemné melódie a verejnoprávne Slovensko 1, ktorému sa darilo lepšie ako rádiu Europa 2. Poradie jednotlivých rádií je rovnaké ako v predošlých dvoch rokoch. (Tabul'ka 9)

Tabul'ka 9 Objem reklamy v rádiách v eurách

\begin{tabular}{|l|c|c||c|}
\hline \multirow{2}{*}{ Medium } & \multicolumn{2}{c||}{ Objem reklamy v $\boldsymbol{2}$} & \multirow{2}{*}{ Zmena v $\boldsymbol{2 0 1 1}$} \\
\cline { 2 - 4 } & $\mathbf{2 0 1 2}$ & 23608695 & $12.4 \%$ \\
\hline Rádio Expres & 26537998 & 18807150 & $5.0 \%$ \\
\hline FUN Rádio & 19742957 & 13422795 & $-3.9 \%$ \\
\hline Rádio Viva & 12896492 & 7699319 & $15.3 \%$ \\
\hline Rádio Jemné melódie & 8879764 & 7372806 & $1.4 \%$ \\
\hline Slovensko 1 & 7473670 & 5782824 & $-2.3 \%$ \\
\hline Európa 2 & 5648753 & & \\
\hline
\end{tabular}

Zdroj: www.tns-global.sk

V roku 2012 slovenské rádiá odvysielali takmer 280 tisíc reklamných spotov v celkovej dížke 1978 hodín vysielania v celkovej hodnote vyše 81 miliónov eur. V medziročnom porovnaní vzrástol počet odvysielaných spotov o $3 \%$. (Tabul'ka 10)

Tabul'ka 10 Prehl'ad rádií podl'a počtu odvysielaných reklamných spotov a dížky odvysielaných spotov

\begin{tabular}{|l|c|c||c|c|c||c|}
\hline \multirow{2}{*}{ Medium } & \multicolumn{2}{|c|}{ Počet odvysielaných spotov } & \multicolumn{3}{c|}{ DÍžka spotov v hodinách } \\
\cline { 2 - 7 } & $\mathbf{2 0 1 2}$ & $\mathbf{2 0 1 1}$ & \% zmena & $\mathbf{2 0 1 2}$ & $\mathbf{2 0 1 1}$ & \% zmena \\
\hline Rádio Viva & 76829 & 80278 & $-4.3 \%$ & 503 & 526 & $-4.4 \%$ \\
\hline FUN rádio & 54260 & 55242 & $-1.8 \%$ & 364 & 381 & $-4.5 \%$ \\
\hline Jemné melódie & 48339 & 40157 & $20.4 \%$ & 326 & 274 & $19.0 \%$ \\
\hline Rádio Expres & 45546 & 39726 & $14.7 \%$ & 322 & 297 & $8.2 \%$ \\
\hline Európa 2 & 37122 & 39119 & $-5.1 \%$ & 336 & 362 & $-7.0 \%$ \\
\hline Slovensko 1 & 17775 & 17762 & $0.1 \%$ & 127 & 139 & $-8.4 \%$ \\
\hline Spolu & 279871 & 272284 & $2.8 \%$ & 1978 & 1979 & $0.0 \%$ \\
\hline
\end{tabular}

Zdroj: www.tns-global.sk

Najväčší podiel pripadá na reklamné spoty odvysielané v časovom intervale od 07:00 do 09:00 hodiny, ked' l'udia cestujú do práce. O niečo menej reklám bolo odvysielaných v d'alšom dopoludňajšom pásme, ktorému konkuruje čas druhej dopravnej špičky na cestách medzi 15-tou až 17-tou hodinou. (Tabul'ka 11)

Tabul'ka 11 Počet odvysielaných spotov počas dňa

\begin{tabular}{|l|c|}
\hline Časové pásmo & Počet odvysielaných spotov \\
\hline Do 6:59 & $6 \%$ \\
\hline Od 7:00 do 08:59 & $19 \%$ \\
\hline Od 9:00 do 10:59 & $17 \%$ \\
\hline Od 11:00 do 12:59 & $13 \%$ \\
\hline Od 13:00 do $14: 59$ & $14 \%$ \\
\hline Od 15:00 do $16: 59$ & $16 \%$ \\
\hline
\end{tabular}




\begin{tabular}{|l|c|}
\hline Od 17:00 do 18:59 & $12 \%$ \\
\hline Od 19:00 & 4 \\
\hline
\end{tabular}

Zdroj: www.tns-global.sk

Najviac komunikovanou komoditou boli tradičné osobné autá, za nimi nasledovala propagácia časopisov a podpora predaja supermarketov.

V rebríčku TOP 15 najväčších zadávatel'ov rozhlasovej reklamy sa umiestnili 4 automobilky, pričom Škoda Auto Slovensko bola aj najväčším zadávatel'om reklamy v rádiu. (Tabul'ka 12)

Tabul'ka 12 TOP 15 najväčších zadávatel’ov rozhlasovej reklamy

\begin{tabular}{|l|c|}
\hline Zadávatel’ & Výdavky v $€$ \\
\hline Škoda Auto Slovensko & 2309275 \\
\hline Spoločnost’ 7 plus & 2103747 \\
\hline Billa & 1667087 \\
\hline Citroen Slovakia & 1415536 \\
\hline Interpharm & 1400376 \\
\hline TV JOJ & 1233163 \\
\hline Orange Slovensko & 1190294 \\
\hline COOP Jednota Slovensko & 1155232 \\
\hline Ringier Axel Springer Slovakia & 1069458 \\
\hline Hornbach & 1030573 \\
\hline Kika & 1015113 \\
\hline Porsche Slovakia & 945145 \\
\hline Zoznam & 908305 \\
\hline Peugeot Slovakia & 893907 \\
\hline Prvá stavebná sporitelňa & 807726 \\
\hline Zdroj: wWw. & \\
\hline
\end{tabular}

Zdroj: www.tns-global.sk

\section{Internetový reklamný priemysel}

Celkovo pripadá na 15 najväčších slovenských webov až 72 \% všetkých nasadených bannerov v roku 2012. Približne $21 \%$ všetkých nasadených bannerov možno považovat' za selfpromo, teda reklamu na vlastné produkty a značky vlastníkov portálov. Táto skutočnost' má vplyv aj na umiestnenie samotných médií v rebríčku TOP 10 zadávatel’ov.

Ako je uvedené v tabul'ke 13, rebríček zadávatel'ov reklamy na internete vedie Lidl. Medzi top 10 zadávatel'mi sú aj všetci traja mobilní operátori.

Tabul'ka 13 TOP 15 najväčších zadávatel'ov reklamy na internete

\begin{tabular}{|c|l|}
\hline Poradie & Zadávatel' \\
\hline $\mathbf{2}$ & Lidl \\
\hline $\mathbf{3}$ & Slovak Telekom \\
\hline $\mathbf{4}$ & Markíza - Slovakia \\
\hline $\mathbf{5}$ & Kraft Foods Slovakia \\
\hline $\mathbf{6}$ & Telefonica Slovakia \\
\hline $\mathbf{8}$ & Centrum Holdings \\
\hline $\mathbf{9}$ & Fashion days shopping \\
\hline $\mathbf{1 0}$ & Petit Press \\
\hline $\mathbf{1 2}$ & Orange Slovensko \\
\hline $\mathbf{1 3}$ & Tatra banka \\
\hline $\mathbf{1 4}$ & TV Joj \\
\hline $\mathbf{1 5}$ & Beiersdorf Slovakia \\
\hline
\end{tabular}

Zdroj: www.tns-global.sk

Celkový objem online reklamy na serveroch Asociácie internetových médií (AIM) tvoril 5,08 milionov eur. V medziročnom porovnaní ide o pokles o 8,8 \%. 
Najoblúbenejším formátom zadávatel'ov je stále bannerová reklama, ktorá má viac než $51 \%$ podiel (v absolútnych číslach, to činí 2,6 miliónov eur). Na druhom mieste je riadková inzercia ( $23 \%, 1,2$ milionov eur), na 3 . mieste je search so $16 \%$ podielom ( 0,8 milionov eur).

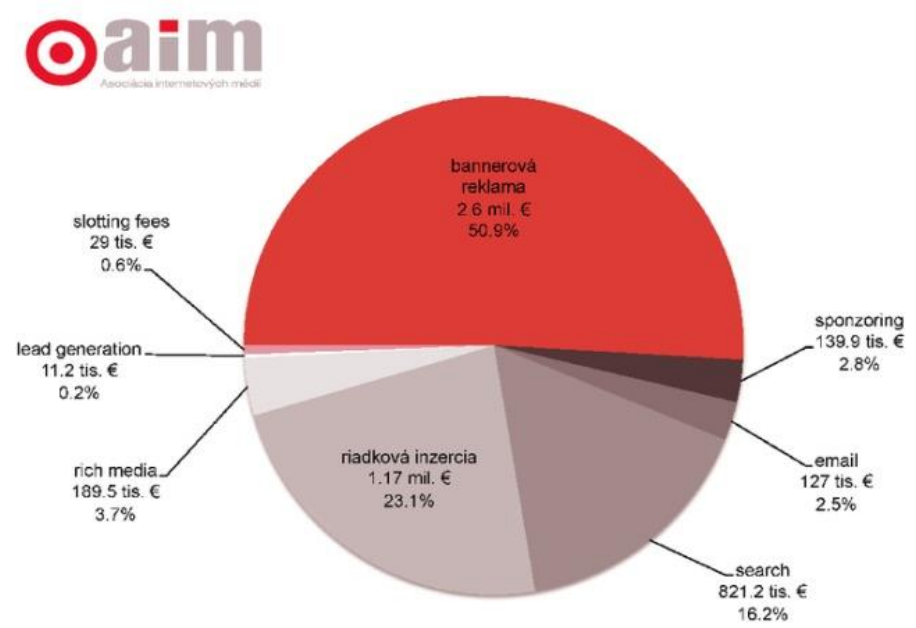

Obrázok 1 Internetová reklama 2009 (Zdroj: www.tns-global.sk)

Z pohl'adu reklamných typov najviac medziročne narástol objem rich media (o $252 \%$ ) a lead generation (o $139 \%$ ). (Obrázok 2). Najviac peňazí utratia spoločnosti zo segmentu telekomunikácií $(25,4 \%)$, z finančného sektoru (18,3\%), automobilového priemyslu $(13,3$ $\%)$, potravinárstva $(9,4 \%)$ a služieb $(8,7 \%)$. (Obrázok 3$)$

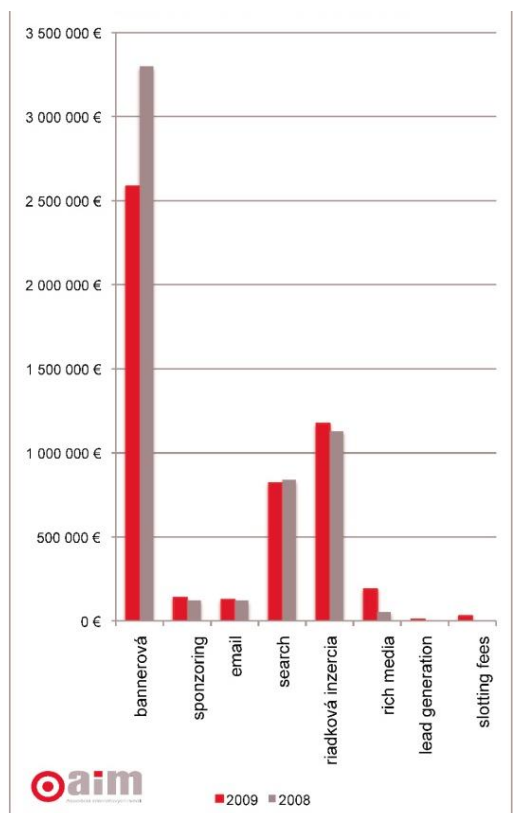

Obrázok 2 Reklamné typy 2008 a 2009

Zdroj: www.tns-global.sk

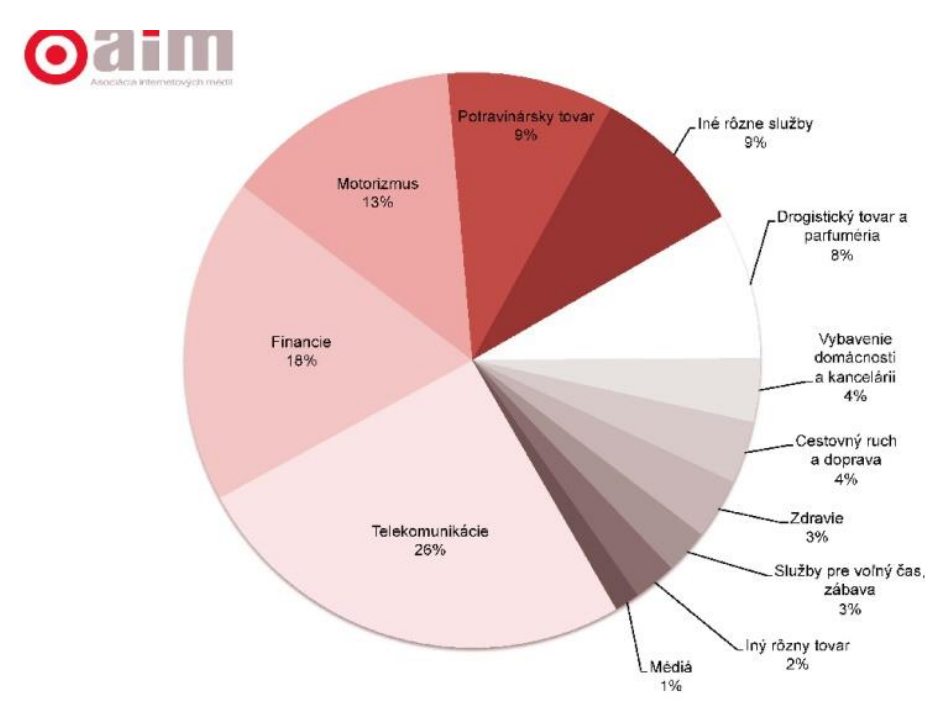

Obrázok 3 Podiel odvetvia v bannerovej reklame a rich media 2009

Zdroj: www.tns-global.sk

\section{Reklama v kino priemysle}

Mediálnym segmentom, do ktorého prúdi najmenej peňazí, je kino reklama. Napriek tomu to však nie je oblast' úplne nezaujímavá.

V kine možno využit' dva druhy reklamy - on-screen a off-screen. Off-screen ponúka napríklad reklamu na vstupenkách, sponzoring premietacích sál, distribúciu pri pokladniach a 
reklamu $\mathrm{v}$ priestoroch kina (na sedačkách). Off-screen reklama predstavuje teda skôr doplnkovú reklamu v kinách.

Tá dôležitejšia reklama je práve on-screen. Diváci si radi pozrú upútavku na nové filmy. $\mathrm{V}$ poslednej dobe došlo preto $\mathrm{k}$ posunu reklamných blokov medzi tieto filmové upútavky. Diváci sú tak lepšie sústredení na reklamu a následne si ju aj lepšie zapamätajú. Výskumy ukazujú, že 80 \% divákov si po filme pamätá 1 reklamu a $71 \%$ dve a viac reklám, ktoré boli pred filmom uvedené.

Reklamy v kinách sa však len málokedy odlišujú od tých, ktoré môžeme vidiet' v televízii. Niektoré firmy sa ale rozhodli vytvorit' spoty určené špeciálne len pre kiná. Aby ňou naozaj zaujali, vniesli do nej prvky interaktivity. [6]

Product placement na Slovensku funguje v televíziách, kde roztáča ozajstné peniaze. Filmárom firmy dôverujú menej. Sponzorstvo je vzácne, väčšinou ide o materiálnu podporu, poskytujú autá, oblečenie, materiál. [7]

\section{Reklamné billboardy}

Slovensko je král'ovstvom bilbordov. Ulice, fasády, aj prírodu pri dial'niciach zamorila reklama, ktorá púta pozornost' a zarába na našich pohl'adoch. Sú takmer všade. Megabordy, citylighty, reklama na autobusoch, električkách, zastávkach hromadnej dopravy. Nevkusné plagáty, obrovské reklamy na fasádach, krikl'avé pútače a výklady obchodov. [8]

Kým v susedných Čechách sa na tému pútačov pri cestách vedú vášnivé spory a $\mathrm{v}$ niektorých krajinách Európskej únie sú dokonca celkom zakázané, u nás je ticho. Pútače lemujú cesty aj napriek tomu, že Národná dial'ničná spoločnost', Slovenská správa ciest, Ministerstvo dopravy i polícia zhodne tvrdia, že aspoň pri cestách vyšších tried by byt' nemali. Ich umiestňovanie $\mathrm{v}$ takzvaných ochranných pásmach dial'nic a ciest pre motorové vozidlá dokonca zakazuje zákon. Bilbordové spoločnosti naopak tvrdia, že negatíva pútačov pri cestách sa preceňujú. Seriózna štúdia, ktorá by preukázala vplyv pútačov na bezpečnost' premávky a ráz krajiny, však doteraz na Slovensku nebola spracovaná. [9]

\section{Dopyt a ponuka v reklamnom odvetví na trhu práce}

Dopyt po pracovníkoch v reklamnom odvetví má stúpajúcu tendenciu, svedčí o tom aj tá skutočnost', že medziročne stúpol počet zverejnených pracovných ponúk v oblasti marketing, reklama, PR o 2\%. [10]

Priemerná nominálna mesačná mzda zamestnancov $\mathrm{v}$ oblasti reklamy závisí od pracovnej pozície. Priemerný plat pre jednotlivé pozície je zobrazený v tabul'ke 14.

Tabul'ka 14 Priemerná nominálna mesačná mzda zamestnancov v oblasti reklamy

\begin{tabular}{|l|c|c|c|}
\hline & Priemerný plat & Plat v Bratislave & Plat mimo BA \\
\hline Reklama & & & \\
\hline Sccount manager - reklama & $1110 €$ & $1110 €$ & N/A \\
\hline Brand manager & $1800 €$ & $1800 €$ & N/A \\
\hline Art director & $1200 €$ & $1200 €$ & N/A \\
\hline Copywriter & $1970 €$ & $1970 €$ & N/A \\
\hline Grafik & $1350 €$ & $1350 €$ & $600 €$ \\
\hline Web dizajnér & $800 €$ & $980 €$ & $890 €$ \\
\hline Mediálne agentúry & $1250 €$ & $1460 €$ & \\
\hline Nákupca médii/ Mediabuyer & & & N/A \\
\hline Mediaplaner & 840 & 840 & N/A \\
\hline
\end{tabular}

Zdroj: http://www.naseplaty.sk/prehlad-platov/media-reklama-pr.html 


\section{Záver}

Reklamný priemysel je rýchlo rastúce odvetvie a $\mathrm{v}$ značnej miere sa podiel'a na hrubom domácom produkte $\mathrm{v}$ ktorejkol'vek krajine. Okrem toho, že reklamný priemysel funguje ako spojovací článok medzi výrobcami, poskytovatel'mi služieb a ich zákazníkmi, zohráva tiež dôležitú úlohu $\mathrm{v}$ ekonomike krajiny. Toto odvetvie si vyžaduje investície na financovanie rôznych aktivít. Medzi hlavné pozitívne vplyvy reklamného priemyslu na ekonomiku sa zarad'ujú tieto aspekty [11]:

- stimuluje konkurenciu;

- predstavuje časovo a finančne efektívnejší nástroj distribúcie informácií, ako je individuálne vyhl'adávanie;

- vedie $\mathrm{k}$ porovnávaniu cien a tým $\mathrm{k}$ existencii menších rozdielov v cenách;

- umožňuje firmám získat' nových zákazníkov pre svoje inovované produkty;

- podporuje znižovanie výrobných nákladov;

- zvyšuje spotrebu;

- zvyšuje tempo zavedenia nových technológií.

Reklamný priemysel je dôležitý tiež pre masmediálny sektor, pretože reklamy sa podiel'ajú na financovaní komerčných televízií, tlače, časopisov a komerčných rádí́.

\section{Literatúra}

[1] HECZKOVÁ,Miroslava.: Základy marketingu, OPF Karviná, 1998

[2] PRACHÁR, J.:Princípy a technika reklamy, Alfa, 1982, str. 242

[3] http://ideakova.gaya.sk/text/Diplomovapraca.pdf

[4] http://www.euroekonom.sk/download2/diplomovka-teoria-marketing/TeoriaDiplomova-praca-Reklama.pdf

[5] www.tns-global.sk

[6] http://hn.hnonline.sk/v-kine-sa-mozno-zabavit-este-pred-filmom-258058

[7] http://kultura.sme.sk/c/6259979/product-placement-kolko-reklamy-vo-filmeznesieme.html

[8] http://spravy.pravda.sk/regiony/clanok/210973-v-ziline-sa-chcu-zbavit-bilbordov/

[9] http://www.sme.sk/c/3317313/bilbordy-pri-cestach-prekazaju-je-ichvela.html\#ixzz2yOLTCTo7

[10] http://www.profesia.sk/cms/newsletter/april-2013/ponuk-na-dohodu-je-oprotivlanajsku-menej/44255

[11] The Contribution of the Advertising Industry to the UK Economy. November 2011. [online]. [s.a.]. [Citované 2012-05-27]. Dostupné na: <http://www.theworkfoundation.com/DownloadPublication/Report/295_The\%20contri bution\%20of\%20advertising\%20to\%20the\%20UK\%20economy\%20311011.pdf $>$.

\section{Grantová podpora}

APVV-0101-10 Kreatívna ekonomika - národohospodárske a regionálne podmienky a stimuly KRENAR

VEGA 1/0421/12 Modelovanie difúzie znalostí v podnikových hodnotových ret’azcoch 